\title{
Б. Б. Cамура
}

\section{Циркулюючий VE-кадгерин і прогноз кардіоваскулярних подій у ремісії множинної мієломи 1Запорізький державний медичний університет, ${ }^{2}$ КУ «Запорізька обласна клінічна лікарня» ЗОР}

Ключові слова: VЕ-кадгерин, кардіоваскулярні подї, множинна мієлома, виживання, прогноз.

Мета роботи - виявлення прогностичної значущості циркулюючого VE-кадгерину у виникненні кардіоваскулярних подій, виживаності пацієнтів із множинною мієломою в повній або частковій ремісії.

Матеріали та методи. У дослідження включили 116 пацієнтів із множинною мієломою в ремісії, період спостереження становив 3 роки. Плазму крові відбирали для визначення рівня циркулюючого VE-кадгерину за допомогою імуносорбентного методу.

Результати. За період спостереження у 41 хворого виявили прогресію множинної мієломи, 6 осіб вибули 3 дослідження у зв’язку 3 відсутністю на черговому візиті. 69 пацієнтів, які залишилися в дослідженні, включили в дальший аналіз. 3 них у 37 (53,6\%) хворих зафіксували 193 кардіоваскулярні події: 14 смертей із кардіоваскулярної причини, 90 кардіальних аритмій, 13 кардіальних ішемічних подій, 6 інсультів, 21 випадок виникнення хронічної серцевої недостатності, 49 госпіталізацій, що пов'язані з кардіоваскулярними причинами. Зафіксовано 28 смертей, котрі не пов’язані з серцево-судинною патологією.

Медіана циркулюючого VE-кадгерину в пацієнтів без кардіоваскулярних подій становила 0,51 нг/мл (95\% довірчий інтервал (ДI) - 0,21-0,81 нг/мл), у пацієнтів 3 кардіоваскулярними подіями - 1,30 нг/мл (95\% ДІ=0,79-1,81 нг/мл) (p=0,02). Мультиваріантний регресійний аналіз показав, що циркулюючий VE-кадгерин $є$ незалежним прогностичним фактором виникнення кардіоваскулярних подій (коефіцієнт регресії 1,$14 ; 95 \%$ ДІ $=1,05-1,17$; $=0,001$ ) протягом 3 років. Водночас наявність цукрового діабету, артеріальної гіпертензії, ожиріння, гіпертрофії лівого шлуночка не показали прогностичної значущості.

Висновки. Серед пацієнтів із документованою множинною мієломою підвищення циркулюючого VE-кадгерину асоціюється 3 виникненням кардіоваскулярних подій протягом 3 років.

\section{Циркулирующий VE-кадгерин и прогноз кардиоваскулярных событий в ремиссии множественной миеломы \\ Б. Б. Самура}

Цель работы - выявление прогностической значимости циркулирующего VE-кадгерина в возникновении кардиоваскулярных событий, выживаемости пациентов с множественной миеломой в ремиссии.

Материалы и методы. В исследование были включены 116 пациентов с множественной миеломой в полной или частичной ремиссии, период наблюдения составил 3 года. Забор плазмы крови производился для определения уровня циркулирующего VE-кадгерина с помощью иммуносорбентного метода.

Результаты. За период наблюдения у 41 пациента выявили прогрессию множественной миеломы, 6 человек выбыли из исследования в связи с отсутствием на очередном визите. Оставшиеся в исследовании 69 пациентов были включены в дальнейший анализ. Из них у 37 (53,6\%) человек зафиксировано 193 кардиоваскулярных события: 14 смертей вследствие кардиоваскулярной причины, 90 кардиальных аритмий, 13 кардиальных ишемических событий, 6 инсультов, 21 случай возникновения хронической сердечной недостаточности, 49 госпитализаций, связанных с кардиоваскулярными причинами. У 28 была зафиксирована смерть, не связанная с сердечно-сосудистой патологией.

Медиана уровня циркулирующего VE-кадгерина у пациентов без кардиоваскулярных событий и с кардиоваскулярными событиями составила 0,51 нг/мл (95\% доверительный интервал [ДИ]=0,21-0,81 нг/мл) и 1,30 нг/мл (95\% ДИ=0,79-1,81 нг/мл), соответственно $(\mathrm{p}=0,02)$. Мультивариантный регрессионный анализ показал, что циркулирующий VE-катгерин является независимым прогностическим фактором возникновения кардиоваскулярных событий (коэффициент регрессии $-1,14 ; 95 \%$ ДИ=1,05-1,17; p=0,001) на протяжении 3 лет. В то же время наличие сахарного диабета, артериальной гипертензии, ожирения, гипертрофии левого желудочка не показали прогностической значимости.

Выводы. Среди пациентов с документированной множественной миеломой в ремиссии повышение циркулирующего VE-кадгерина ассоциируется с возникновением кардиоваскулярных событий на протяжении 3 лет.

Ключевые слова: VЕ-кадгерин, кардиоваскулярные события, множественная миелома, выживаемость, прогноз.

Запорожский медицинский журнал. - 2016. - №3 (96). - С. 10-14

\section{Circulating VE-catherin and prognosis of cardiovascular events in remission of multiple myeloma}

\section{B. B. Samura}

Objective. We aimed to evaluate the prognostic value of circulating VE-catherin for cumulative survival in patients with multiple myeloma in full or partial remission.

Materials and methods. One hundred sixteen patients with multiple myeloma with complete or partial remission were enrolled in the study. Observation period was up to 3 years. Blood samples for biomarkers measurements were collected. ELISA method for measurements of circulating level of VE-catherin was used.

Results and Conclusions. During observation period progression of multiple myeloma was proved in 41 patients, 6 persons were excluded for poor follow-up. One hundred ninety three cumulative clinical events occurred in 37 patients $(53.6 \%)$ within the follow-up, with their distribution being as follows: 14 cardiovascular deaths, 90 cardiac arrhythmias, 13 cardiac ischemic events, 6 strokes, 21 chronic heart failures and 49 hospital admissions for cardiovascular reasons. 28 deaths were not related with cardiovascular pathology.

Medians of circulating levels of VE-catherin in free-events subject cohort and subjects cohort with cardiovascular events were $0.51 \mathrm{ng} /$ $\mathrm{ml}(95 \%$ confidence interval $[\mathrm{CI}]=0.21-0.81 \mathrm{ng} / \mathrm{ml})$ and $1.30 \mathrm{ng} / \mathrm{ml}(95 \% \mathrm{CI}=0.79-1.81 \mathrm{ng} / \mathrm{ml})(\mathrm{p}=0.02)$. In multivariate logistic regression 
circulating VE-catherin independently predicted cumulative cardiovascular events (odds ratio $[\mathrm{OR}]=1.14 ; 95 \% \mathrm{CI}=1.06-1.17 ; \mathrm{p}=0.001)$ within 3 years of observation period.

Among patients with documented multiple myeloma in remission increased circulating VE-catherin associates with increased cumulative cardiovascular events.

Key words: VE-catherin, Cardiovascular Events, Multiple Myeloma, Survival, Prognosis.

Zaporozhye medical journal 2016; №3 (96): 10-14

$\mathrm{M}$ ножинна мієлома є інкурабельним онкологічним захворюванням і залишається другим за поширеністю онкогематологічним захворюванням в Свропі. Виживання пацієнтів за останні 15 років значно поліпшилось завдяки використанню більш активних і менш токсичних ліків [14]. Збільшення виживання хворих на множинну мієлому, до яких переважно належать люди середнього та похилого віку, є причиною збільшення впливу кардіоваскулярних подій на загальне виживання. Виникнення кардіоваскулярних подій може бути асоційовано 3 лікуванням, амілоїдозом міокарда, ендотеліальним пошкодженням і периваскулярною плазмоцитарною інфільтрацією. Показана пряма залежність між щільністю мікросудин при лімфопроліферативних неоплазіях і прогресуванням захворювання [4].

Під час множинної мієломи продукція індукторів ангіогенезу збільшується, а синтез інгібіторів ангіогенезу зменшується. Ангіогенез при неоплазіях суттєво відрізняється від фізіологічного ангіогенезу у зв'язку з хаотичним синтезом індукторів ангіогенезу, що призводить до аберантної структури судин, зміни міжклітинних взаємодій, порушення нормального кровотоку, збільшення проникливості судинної стінки. Тому регулятори ангіогенезу при множинній мієломі мають прогностичний потенціал $[1,16,20]$.

Судинний ендотеліальний кадгерин (VE-кадгерин) має принципове значення в ангіогенезі, неоваскуляризації, рості пухлинних клітин, стимулюванні стовбурних клітин, інтеграції ендотеліоцитів $[5,6,9,15]$. При множинній мієломі кадгерини (VE-кадгерин, N-кадгерин) разом з інтегринами (VLA-4, VLA-5) і клітинами молекулярної адгезії (VCAM, MAdCAM, NCAM) мають важливе значення у взаємодії між пухлинною клітиною та стромою кісткового мозку $[3,8,10,11,19]$. VE-кадгерин як трансмембранний протеїн може модулювати інтенсивність ангіогенезу при лімфопроліферативних неоплазіях, а отже виправданим є його застосування для прогнозу відповіді на лікування $[17,18]$. Однак прогностична роль VE-кадгерину як маркера кардіоваскулярних подій у пацієнтів із множинною мієломою залишається нез'ясованою.

\section{Мета роботи}

Визначення прогностичного значення циркулюючого VE-кадгерину у виникненні кардіоваскулярних подій, виживанні пацієнтів із множинною мієломою в ремісії.

\section{Матеріали і методи дослідження}

У дослідження включено 116 хворих на множинну мієлому з повною або частковою ремісією. Підтвердження діагнозу та лікування множинної мієломи здійснені згідно 3 клінічними протоколами $[7,13]$. Дослідники суворо дотримувались усіх вимог клінічних досліджень згідно з Гельсінською декларацією прав людини (1964), Конференцією 3 гармонізації належної клінічної практики (GCP-ICH),
Конвенцією Ради Європи про захист прав і гідності людини у зв'язку з застосуванням досягнень біології та медицини, Конвенцією про права людини та біомедицину, включаючи Додатковий протокол до Конвенції про біомедичні дослідження, й законодавством України.

Після підписання інформованої згоди всім пацієнтам виконали загальноклінічне обстеження. Оцінювання гемодинаміки здійснювали за допомогою трансторакальної ехокардіографії за загальноприйнятою методикою на сканері «MyLab 50» (Італія) в M- і В-режимах ехолокації з парастернальної, субкостальної та апікальної позиції по короткій та довгій осям датчиком із частотою 2,5-3,5 MHz. Кінцево-діастолічний (КДО) та кінцево-систолічний (КСО) об’ єми лівого шлуночка вимірювали планіметричним модифікованим методом Сімпсона, а у випадку верифікації тяжких порушень локальної скорочувальної функції міокарда — методом циліндрів [2]. Фракцію викиду лівого шлуночка (ФВ) та індекс регіональної скорочувальної функції лівого шлуночка оцінювали згідно з вимогами Американського товариства ехокардіографії.

Зразки крові для визначення рівня VE-кадгерину брали у ранкові часи (7.00-8.00) в охолоджені силіконові пробірки та центрифугували зі швидкістю 6000 об/хв протягом 15 хв. Після цього плазму крові заморожували та зберігали при температурі не більше ніж $-35^{\circ} \mathrm{C}$. Рівень VE-кадгерину був визначений за допомогою техніки ELISA з використанням наборів Human VE-cadherin Quantikine ELISA Kit (R\&G, United Kingdom). У плазмі крові концентрацію глюкози, глікованого гемоглобіну (HbAlc), загального холестерину, ліпопротеїдів високої щільності (ЛПВЩ), ліпопротеїдів низької щільності (ЛПНЩ), тригліцеридів, креатиніну визначали згідно зі стандартними методиками.

Загальна характеристика пацієнтів наведена у таблиці 1 .

Клінічні візити здійснювали кожен місяць протягом 3 років після включення в дослідження, під час яких фіксували кардіоваскулярні події: інсульт, транзиторну ішемічну атаку, смерть унаслідок будь-якої причини; смерть унаслідок кардіоваскулярної причини, коронарні ішемічні події (інфаркт міокарда, нестабільна стенокардія), госпіталізацію внаслідок кардіоваскулярної причини; вперше встановлену серцеву недостатність, прогресію множинної мієломи. Інсульти підтверджені комп'ютерною томографією.

Статистичний аналіз здійснювали за допомогою програми SPSS для Windows v. 17.0 (SPSS Inc., Chicago, IL, CШA).

Для кожної з безперервних величин залежно від їх типу розподілу визначали або середню (М) і стандартне відхилення ( $\sigma)$, або медіану й квартилі розподілу. Порівнюючи групи пацієнтів за основними показниками (залежно від типу розподілу показників, котрі аналізуються), застосовували безперервний непарний t-критерій Стьюдента або U-критерій Манна-Уітні. 
Загальна характеристика пацієнтів

\begin{tabular}{|c|c|c|c|}
\hline Показник & $\begin{array}{c}\text { Група без кардіоваскулярних } \\
\text { подій }(\mathrm{n}=32)\end{array}$ & $\begin{array}{c}\text { Група з кардіоваскулярними } \\
\text { подіями }(\mathrm{n}=37)\end{array}$ & $\mathrm{p}$ \\
\hline Вік, роки & $58 \pm 7,33$ & $62 \pm 8,44$ & 0,03 \\
\hline Чоловіки, n (\%) & $7(21,9)$ & $20(54,1)$ & 0,01 \\
\hline Артеріальна гіпертензія, n (\%) & $3(9,4)$ & $9(24,3)$ & 0,11 \\
\hline Дисліпідемія, n (\%) & $6(18,8)$ & $7(18,9)$ & 0,99 \\
\hline Цукровий діабет 2 типу, n (\%) & $1(3,1)$ & $1(2,7)$ & 0,93 \\
\hline $\mathrm{IMT}, \mathrm{kr} / \mathrm{M}^{2}$ & 26,97 (95\% ДИ=25,34-28,61) & 27,99 (95\% ДИ=25,64-27,93) & 0,99 \\
\hline Ожиріння, n (\%) & $4(12,5)$ & $2(5,4)$ & 0,31 \\
\hline Надлишкова маса тіла, n (\%) & $10(31,3)$ & $12(32,4)$ & 0.92 \\
\hline Прихильність до тютюнопаління, n (\%) & $0(0,0)$ & $2(5,4)$ & \\
\hline ШКФ, мл/хв/1,73 м² & $100,3 \pm 18,48$ & $100,5 \pm 20,54$ & 0,70 \\
\hline $\mathrm{HbA} 1 \mathrm{c}, \%$ & $5,05 \pm 0,70$ & $5,18 \pm 0,66$ & 0,37 \\
\hline Глюкоза, ммоль/л & $4,66 \pm 0,49$ & $4,61 \pm 0,54$ & 0,69 \\
\hline Креатинін, ммоль/л & $67,97 \pm 14,31$ & $69,32 \pm 14,40$ & 0,56 \\
\hline Загальний холестерин, ммоль/л & $5,22 \pm 0,90$ & $4,94 \pm 0,67$ & 0,12 \\
\hline ЛПНЩ, ммоль/л & $2,85 \pm 0,86$ & $2,97 \pm 0,84$ & 0,80 \\
\hline лПВЩ, ммоль/л & $1,53 \pm 0,31$ & $1,45 \pm 0,39$ & 0,63 \\
\hline САТ, мм рт. ст. & $123,8 \pm 13,43$ & $128,2 \pm 13,09$ & 0,28 \\
\hline ЧСС, удари за 1 хв. & $81,06 \pm 8,90$ & $80,16 \pm 9,07$ & 0,77 \\
\hline$\Phi \mathrm{B}, \%$ & $57,26 \pm 4,32$ & $56,89 \pm 4,11$ & 0,76 \\
\hline E/A, од. & $1,14 \pm 0,25$ & $1,15 \pm 0,22$ & 0,90 \\
\hline E/E', од. & $6,73 \pm 1,64$ & $7,86 \pm 1,93$ & 0,02 \\
\hline ІАПФ або APAII, n (\%) & $3(9,4)$ & $10(27,0)$ & 0,07 \\
\hline Ацетилсаліцилова кислота, n (\%) & $24(75,0)$ & $32(86,5)$ & 0,23 \\
\hline Статіни, n (\%) & $25(78,1)$ & $11(29,7)$ & $<0,0001$ \\
\hline Метформін, n (\%) & $0(0,0)$ & $1(2,7)$ & 0,02 \\
\hline Диуретики, n (\%) & $2(6,3)$ & $9(33,3)$ & 0,04 \\
\hline Антагоністи альдостерону, n (\%) & $3(9,4)$ & $5(13,5)$ & 0,60 \\
\hline
\end{tabular}

Для аналізу таблиць спряженості $2 \times 2$ застосовували двосторонній точний критерій Фішера та критерій $\chi^{2}$. Потенційні фактори (вік, стать, тютюнопаління, систолічний артеріальний тиск (САТ), діастолічний артеріальний тиск (ДАТ), VЕ-кадгерин, глюкоза, холестерин, тригліцериди, ЛПНЩ, креатинін, HbA1c), які можуть бути пов'язані з кардіоваскулярними подіями, визначали спочатку за допомогою уніваріантного аналізу (ANOVA), потім за допомогою мультиваріантного регресійного аналізу. При $\mathrm{p}<0,05$ різницю даних розцінювали як статистично значущу.

\section{Результати та їх обговорення}

За період спостереження у 41 пацієнта виявили прогресію множинної мієломи, 6 пацієнтів вибули з дослідження у зв'язку з відсутністю на візиті. 69 пацієнтів були включені в наступний аналіз. 3 них у 37 (53,6\%) пацієнтів зафіксовано 193 кардіоваскулярні події: 14 смертей унаслідок кардіоваскулярної причини, 90 кардіальних аритмій, 13 кардіальних ішемічних подій, 6 інсультів, 21 випадок виникнення хронічної серцевої недостатності, 49 госпіталізацій внаслідок кардіоваскулярних подій. Зафіксовано 28 не пов'язаних із кардіоваскулярною патологією смертей.

При аналізі демографічних характеристик виявлено незначне переважання чоловіків похилого віку у групі пацієнтів із кардіоваскулярними подіями. Не зафіксовано різниці між обома когортами пацієнтів за факторами ризику (тютюнопаління, артеріальна гіпертензія, дисліпідемія, цукровий діабет 2 типу, індекс маси тіла (IMT), ожиріння), біохімічними показниками (креатинін, швидкість клубочкової фільтрації (ШКФ), загальний холестерин, ЛПНЩ, ЛПВЩ, глюкоза, HbA1c) і деякими гемодинамічними показникам (САТ, ДАТ, частота серцевих скорочень (ЧСС), ФВ, відношення пікової швидкості пізнього діастолічного наповнення ЛШ до пікової швидкості пізнього діастолічного наповнення ЛШ (Е/A).

3 іншого боку, виявлені вищі цифри відношення пікової швидкості пізнього діастолічного наповнення лівого шлуночка до ранньої діастолічної міокардіальної швидкості (E/E') у групі пацієнтів із кардіоваскулярними подіями. 
Усі пацієнти з артеріальною гіпертензією отримали лікування згідно з рекомендаціями щодо модифікації дієти, стилю життя, приймання препаратів, а саме: інгібіторів ангіотензинперетворювального ферменту (ІАПФ) або антагоністів рецепторів до ангіотензину II (APAII), ацетилсаліцилової кислоти та інших антиагрегантів, статинів. Метформін був призначений одному пацієнту з цукровим діабетом 2 типу з групи хворих із кардіоваскулярними подіями, в інших випадках рівень глюкози контролювався дотриманням дієти та модифікацією стилю життя. У зв’язку з тим, що ознаки серцевої недостатності спостерігали у групі хворих із кардіоваскулярними подіями, в цій групі частіше застосовували ІАПФ, АРАІІ, антагоністи мінералкортикоїдних рецепторів, діуретики.

Медіани рівня циркулюючого VE-кадгерину у пацієнтів без кардіоваскулярних подій і з кардіоваскулярними подіями становили 0,51 нг/мл (95\% довірчий інтервал [ДІ] $=0,21-0,81$ нг/мл) и 1,30 нг/мл (95\% ДІ=0,79-1,81 нг/мл), відповідно ( $\mathrm{p}=0,02)$ (рис. 1$)$.

Результати вказують на прямий зв'язок між VE-кадгерином i E/E' (r=0,41, p=0,03). Уніваріантний і мультиваріантний регресійні аналізи застосовували для розмежування двох когорт за допомогою біомаркера. Під час уніваріантного регресійного аналізу головними факторами, котрі були незалежно пов'язані з кардіоваскулярними подіями, були $\mathrm{VE-кадгерин,} \mathrm{E/E'.} \mathrm{Мультиваріантний} \mathrm{регресійний} \mathrm{ана-}$ ліз визначив VE-кадгерин незалежним прогностичним маркером кардіоваскулярних подій (відношення шансів [ВШ] $=1,12 ; 95 \%$ ДI=1,03-1,15; $\mathrm{p}=0,001)$ протягом 3 років спостереження. Цукровий діабет 2 типу, ожиріння, ФВ не мали предикторних властивостей.

Незважаючи на міжнародні протоколи лікування множинної мієломи, залишається різниця в результатах лікування пацієнтів у межах великих досліджень. Залишаються невизначеними фактори, що впливають на цю різницю. 3'ясовано, що частина пацієнтів із множинною мієломою мають високий кардіоваскулярний ризик у зв'язку з хао-

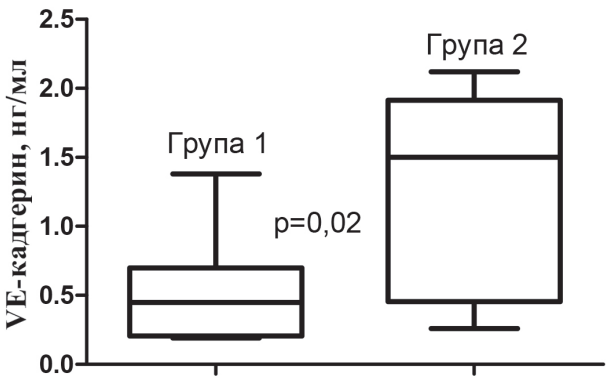

Puc. 1. Рівень циркулюючого VE-кадгерину в пацієнтів із повною або частковою ремісією множинної мієломи без кардіоваскулярних подій (група 1) і 3 кардіоваскулярними подіями (група 2) протягом 3 років спостереження.

тичним синтезом індукторів ангіогенезу, порушеннями в інтеграції ендотеліоцитів і неоваскуляризації. Традиційне лікування, яке застосовується в більшості пацієнтів із множинною мієлом ою, може погіршувати ендотеліальну функцію. У цьому аспекті виглядають обнадійливо біологічні маркери, котрі є регуляторами ангіогенезу.

Підвищення рівня циркулюючого VE-кадгерину асоціюється зі збільшенням ризику кардіоваскулярних подій у пацієнтів із множинною мієломою. Щобільше, прогностична потужність VE-кадгерину була вищою при комбінації 3 ФВ. Розглядаючи нові біомаркери, необхідно аналізувати покращення стратифікації ризику кумулятивних кардіоваскулярних подій на клінічній прогностичній моделі. Необхідно надалі здійснювати дослідження прогностичної значущості VE-кадгерину в пацієнтів із документованою множинною мієломою.

\section{Висновки}

Серед пацієнтів із повною або частковою ремісією множинної мієломи підвищення рівня циркулюючого VE-кадгерину асоціюється зі збільшенням кумулятивних кардіоваскулярних подій протягом 3 років спостереження.

Конфлікт інтересів: відсутній.

\section{Список літератури}

1. Cavallaro U. Endothelial cadherins and tumor angiogenesis U. Cavallaro, S. Leibner, E. Dejana // Exp. Cell Res. - 2006. Vol. 312(5). - P. 659-667.

2. Fluid shear stress on endothelial cells modulates mechanical tension across VE-cadherin and PECAM-1 / D.E. Conway, M.T. Breckenridge, E. Hinde et al. // Curr. Biol. - 2013. - Vol. 23 (11). - P. 1024-1030

3. Cell adhesion mediated drug resistance (CAM-DR): Role of integrins and resistance to apoptosis in human myeloma cell lines / J.S. Damiano, A.E. Cress, L.A. Hazlehurst et al. // Blood. - 1999. - Vol. 93(5). - P. 1658-1667.

4. Dimopoulos M.A. Multiple myeloma / M.A. Dimopoulos, E. Terpos // Ann Oncol. - 2010. - Vol. 21. - P. 143-150.

5. Gavard J. Endothelial permeability and VE-cadherin: A wacky comradeship / J. Gavard // Cell Adh. Migr. - 2013. - Vol. 7(6). - P. 455-461.

6. George S.J. Cadherin: catenin complex: A novel regulator of vascular smooth muscle cells behaviour / S.J. George, C.A. Beeching // Atherosclerosis. - 2006. - Vol. 188(1). - P. 1-11.

7. International staging system for multiple myeloma / P.R. Greipp, J. San Miguel, B.G.M. Durie et al. //. J. Clin. Oncol. - 2005. Vol. 23(15). - P. 3412-3420.

8. N-cadherin-mediated interaction with multiple myeloma cells inhibits osteoblast differentiation / R.W. Groen, M.F. de Rooij, K.A. Kocemba et al. // Haematologica. -. 2011. - Vol. 96. P. 1653-1661.

9. Gumbiner B.M. Regulation of cadherin-mediated adhesion in morphogenesis / B.M. Gumbiner // Nature Rev. Mol. Cell Biol. 2005. - Vol. 6(8). - P. 622-634.

10. Clinicopathological correlates of plasma cell CD56 (NCAM) expression in multiple myeloma / M. Kraj, U. Sokołowska, J. Kopeć-Szlezak et al. // Leuk. Lymphoma. - 2008. - Vol. 49(2). - P. 298-305.

11. Cell-cell contact between marrow stromal cells and myeloma cells via VCAM-1 and alpha(4)beta(1)-integrin enhances production of osteoclast-stimulating activity / T. Michigami, N. Shimizu, P.J. Williams et al. // Blood. - 2000 - - Vol. 96(5). - P. 1953-1960.

12. Management of Newly Diagnosed Symptomatic Multiple Myeloma: Updated Mayo Stratification of Myeloma and Risk-Adapted Therapy (mSMART) Consensus Guidelines / J.R. Mikhael, D. Dingli, V. Roy et al. // Mayo Clin Proc. - 2013. - Vol. 88(7). - P. 360-376.

13. ESMO Guidelines Working Group. Multiple myeloma: ESMO Clinical Practice Guidelines for diagnosis, treatment and follow-up / P. Moreau, J. San Miguel, H. Ludwig et al. //. Ann Oncol. - 2013. - Vol. 24(6). - P. 133-137. 
14. Understanding what matters most to people with multiple myeloma: a qualitative study of views on quality of life / T.R. Osborne, C. Ramsenthaler, S. de Wolf-Linder et al. //. BMC Cancer. - 2014. - Vol. 14(1). - P. 496.

15. Rubina K.A. T-cadherin is an atypical low-density lipoprotein receptor in vascular cells / K.A. Rubina, V.A. Takchuk // Ross. Fiziol. Zh. Im. I.M. Sechenova. - 2004. - Vol. 90(8). - P. 968-986.

16. Angiogenesis in multiple myeloma / A. Vacca, R. Ria, A. Reale et al. //. Chem Immunol Allergy. - 2014. - Vol. 99. - P. 180-196.

17. Circulating $\mathrm{N}$-cadherin levels are a negative prognostic indicator in patients with multiple myeloma / K. Vandyke, A.W. Chow, S.A. Williams et al. // Br. J. Haematol. - 2013. - Vol. 161(4). P. 499-507.

18. sVE-cadherin and sCD146 serum levels in patients with multiple myeloma / T. Wrobel, G. Mazur, D. Wolowiec et al. //. Clin. Lab. Haematol. - 2006. - Vol. 28(1). - P. 36-39.

19. Detecting methylation patterns of p16, MGMT, DAPK and E-cadherin genes in multiple myeloma patients / O.O. Yuregir, E. Yurtcu, E. Kizilkilic et al. //. Int. J. Lab. Hematol. - 2010. Vol. 32(2). - P. 142-149.

20. Cancer stem cell, niche and EGFR decide tumor development and treatment response: A bio-computational simulation study $/$ X. Zhu, X. Zhou, M.T. Lewis et al. //. J. Theor. Biol. - 2011. Vol. 269(1). - P. 138-149.

\section{References}

1. Cavallaro, U., Leibner, S., \& Dejana, E. (2006) Endothelial cadherins and tumor angiogenesis. Exp. Cell Res., 312 (5): 659-667. doi:10.1016/j.yexcr.2005.09.019.

2. Conway, D. E., Breckenridge, M. T., Hinde, E., Gratton, E., Chen, C. S., \& Schwartz, M. A. (2013) Fluid shear stress on endothelial cells modulates mechanical tension across VE-cadherin and PECAM-1. Curr. Biol., 23(11), 1024-1030. doi: 10.1016/j. cub.2013.04.049.

3. Damiano, J. S., Cress, A. E., Hazlehurst, L. A., Shtil, A. A., \& Dalton, W. S. (1999) Cell adhesion mediated drug resistance (CAM-DR): Role of integrins and resistance to apoptosis in human myeloma cell lines. Blood, 93(5), 1658-1667.

4. Dimopoulos, M. A, \& Terpos, E. (2010) Multiple myeloma. Ann Oncol., 21, 143-150.

5. Gavard, J. (2013) Endothelial permeability and VE-cadherin: A wacky comradeship. Cell Adh. Migr., 7 (6), 455-461. doi: 10.4161/ cam. 27330 .

6. George, S. J., \& Beeching, C. A. (2006) Cadherin: catenin complex: A novel regulator of vascular smooth muscle cells behaviour. Atherosclerosis, 188(1), 1-11. doi:10.1016/j.atherosclerosis.2005.12.017.

7. Greipp, P. R., San Miguel, J., Durie, B. G. M., Crowley, J. J., Barlogie, B., Bladé, J., et al. (2005) International staging system for multiple myeloma. J. Clin. Oncol., 23(15), 3412-3420.

8. Groen R.W., de Rooij M.F., Kocemba K.A., Reijmers, R. M., de Haan-Kramer, A., Overdijk, M. B., et al. (2011) N-cadherin-mediated interaction with multiple myeloma cells inhibits osteoblast differentiation. Haematologica, 96, 1653-1661. doi: 10.3324/ haematol.2010.038133.

9. Gumbiner, B. M. (2005) Regulation of cadherin-mediated adhesion in morphogenesis. Nature Rev. Mol. Cell Biol., 6(8), 622-634. doi:10.1038/nrm1699.

10. Kraj, M., Sokołowska, U., Kopeć-Szlezak, J., Pogłód, R., Kruk, B., Woźniak, J., \& Szpila, T. (2008) Clinicopathological correlates of plasma cell CD56 (NCAM) expression in multiple myeloma. Leuk Lymphoma, 49(2), 298-305. doi: 10.1080/10428190701760532.

11. Michigami T., Shimizu N., Williams P.J., Niewolna, M., Dallas, S. L., Mundy, G. R., \& Yoneda, T. (2000) Cell-cell contact between marrow stromal cells and myeloma cells via VCAM-1 and alpha(4) beta(1)-integrin enhances production of osteoclast-stimulating activity. Blood, 96(5), 1953-1960.

12. Mikhael, J. R., Dingli, D., Roy, V., Reeder, C. B., Buadi, F. K., Hayman, S. R. et al. (2013) Management of Newly Diagnosed Symptomatic Multiple Myeloma: Updated Mayo Stratification of Myeloma and Risk-Adapted Therapy (mSMART) Consensus Guidelines 2013. Mayo Clin Proc., 88(7), 360-376. doi: 10.1016/j. mayocp.2013.01.019.

13. Moreau P., San Miguel J., Ludwig H., Schouten, H., Mohty, M., Dimopoulos, M., Dreyling, M. et al. (2013) ESMO Guidelines Working Group. Multiple myeloma: ESMO Clinical Practice Guidelines for diagnosis, treatment and follow-up. Ann Oncol., 24(6), 133-137. doi: 10.1093/annonc/mdt297.

14. Osborne, T. R., Ramsenthaler, C., de Wolf-Linder, S., Schey, S. A., Sieger, R. J., Edmonds, P. M., \& Higginson, I. J. (2014) Understanding what matters most to people with multiple myeloma: a qualitative study of views on quality of life. BMC Cancer, 14(1), 496. doi: 10.1186/1471-2407-14-496.

15. Rubina, K. A., \& Takchuk, V. A. (2004) T-cadherin is an atypical low-density lipoprotein receptor in vascular cells. Ross. Fiziol. Zh. Im. I.M. Sechenova, 90(8), 968-986.

16. Vacca, A., Ria, R., Reale, A. et al. (2014) Angiogenesis in multiple myeloma. Chem Immunol Allergy, 99, 180-196. doi: 10.1159/000353312.

17. Vandyke K., Chow A.W., Williams S.A., \& Zannettino, A. C. (2013) Circulating N-cadherin levels are a negative prognostic indicator in patients with multiple myeloma. Br. J. Haematol., 161(4), 499-507. doi: 10.1111/bjh.12280.

18. Wrobel T., Mazur G., Wolowiec D., Jazwiec, B., Sowinska, E., \& Kuliczkowski, K. (2006) sVE-cadherin and sCD146 serum levels in patients with multiple myeloma. Clin. Lab. Haematol., 28(1), 36-39.

19. Yuregir, O. O., Yurtcu, E., Kizilkilic, E., Kocer, N. E., Ozdogu, H., \& Sahin, F. I. (2010) Detecting methylation patterns of p16, MGMT, DAPK and E-cadherin genes in multiple myeloma patients. Int. J. Lab. Hematol., 32(2), 142-149. doi: 10.1111/j.1751553X.2009.01146.x

20. Zhu, X., Zhou, X., Lewis, M. T., Xia, L, \& Wong, S. et al. (2011) Cancer stem cell, niche and EGFR decide tumor development and treatment response: A bio-computational simulation study. J. Theor. Biol., 269(1), 138-149. doi: 10.1016/j.jtbi.2010.10.016.

\section{Відомості про автора:}

Самура Б. Б., канд. мед. наук, доцент каф. внутрішніх хвороб 3, Запорізький державний медичний університет, зав. гематологічного відділення, КУ «Запорізька обласна клінічна лікарня» 3ОР, E-mail: samura@mail.ru.

Сведения об авторе:

Самура Б. Б., канд. мед. наук, доцент каф. внутренних болезней 3, Запорожский государственный медицинский университет, зав. гематологическим отделением, КУ «Запорожская областная клиническая больница» 3ОC, E-mail: samura@mail.ru.

\section{Information about author:}

Samura B. B., MD, PhD, Associate Professor of the Department of Internal Diseases 3 of Zaporizhzhia State Medical University, Head of the Hematology Department of Zaporizhzhia Regional Clinical Hospital, E-mail: samura@mail.ru. 